\title{
CONTEXT SPECIFIC DETERMINANTS OF PERFORMANCE OF INFORMAL SECTOR: A STUDY OF FACTOR STRUCTURE
}

\author{
F. H. Abdul Rauf \\ Department of Management, \\ South Eastern University of Sri Lanka, \\ hansiyar@yahoo.com \\ Rukshan Bernard Lovell, \\ Postgraduate Student, \\ Faculty of Management and Commerce, \\ South Eastern University of Sri Lanka, \\ rukshanlovell@gmail.com
}

\begin{abstract}
The objective of this study was to identify the factors influencing the performance of the informal sector in war affected regions of Sri Lanka and to examine the factor structure of it. Regarding to this study the researchers had mixed opinions in the factors influencing the informal sector so action was taken to find the major factors. This study was conducted in two stages. Stage one of the research, the exploratory study contained a factor identification study using the triangulation method with a sample size of 100 women headed households from the Vavuniya District in Si Lanka. Information were gathered from three perspectives, motivating factors, hindering factors and factors recommended to improve performance. Items generated by the responded were undergone content analysis. The content analysis of the exploratory study found four major factors. Consequently, the study of factor structure of the determinants of performance of the informal sector, at the second stage with a sample size of 300 women entrepreneurs engaged in the informal sector was conducted. The results revealed four factors, namely training, education, social and economic, matched with the results of the exploratory study. Implications are also discussed.
\end{abstract}

Keywords: Factor structure, determinants, informal sector, women headed households

\section{Introduction}

In many countries, especially in developing countries the informal sector represents an important segment of the economy and the labour market. Thus, performance of the informal sector is important as well how much it's contributing towards the Gross Domestic Product (GDP). This sector gets even important as the formal sector of the country cannot absorb all the labour force of the country, so the informal sector plays a major role in employment creation, production and income generation. The employment contribution to informal sector in Sri Lanka is 59.5\% in 2014 and by gender male $62.4 \%$ and female $53.9 \%$, 
this sector is very important as an employment generator. However, commonly it is believed that informal sector performance is only at a satisfactory level and that it's not performing at its optimum level due to various reasons. But due to high vulnerability and the closer relationship to working poverty, more attention should pay on this sector in order to eradicate poverty and to achieve decent work conditions of the country.

In Sri Lanka, the quality of life is just at a satisfactory level compared to other developing nations such as South Asian and Asian countries. However, there are inequalities between regions or areas. Particularly the North- East province in Sri Lanka is in a backward position than other provinces (Sri Lanka Labour force survey annual report data, 2014). The people are mostly neglected from the government's major development projects and private sector's activities because of past thirty years of internal war (Ethnic conflict and other violence). Due to these incidents, there were so many persons were missing, deaths, murders, displaced as refugees, loss of assets, destruction of industries and economic infrastructures and capital losses.

In the rebuilding process of the nation the economy of the country, employment creation and incising the earnings of the people are very important. However the majority of the working community are depending on the informal sector for a living. When considering the war affected areas too it the same as a large amount of people are engaged in the informal sector (Sri Lanka Labour force survey annual report data, 2014). One of the author as a humanitarian worker for the last ten years working in the war affected areas of Sri Lanka (North and East) has come across many discussions with government officials, other humanitarian organizations, beneficiaries, banks, civil societies and in his own experience and with long observations realized that the informal sector though holds a large share of employees it is not performing at a potential manner to rebuild the economy of the country so the researcher wanted to study the actual reason for not performing at the expected level or its potential.

On the other hand starting from the poorest of the poor who fully depend on the informal sector, is felt ideal and this study selected the women headed house hold as the target audience, they are the most vulnerable group in the society and by less opportunities in the formal sector they fall in to the category of informal sector. They might not want to be in the informal sector but due to no other options they have to stick in the sector to make a living. These families need to be strengthen as young mothers might have kids who are going to school and need a stable considerable income to take forward the family they will need money for daily food, education, nutrition and other basic needs so to fulfill all these requirements the income should be sufficient. When there are more children in the family the burden increases significantly.

When considering bigger children also the requirements differ and these women will have to think how to settle their children with a good future so they will have to earn a stable sufficient income through their entire life. So when talking about sustainable development and increasing the standard of living of Sri Lankan citizens and this group have to be taken care of. But if the informal sector is not 
performing sufficiently due to some or many reasons they should be first identified and then it should be addressed.

Due to the war there were many women converted as the bread winner of the family as they lost their husbands or by disability, low level of living standard, high rate of population growth and dependency burden, high level of unemployment $3.9 \%$ and underemployment $9.4 \%$ in the year 2014 and primary product exports, low level of income and productivity. Therefore, the people who were living in these areas were suffering in many ways such as insufficient basic needs, lower income, unemployment, lack of education, poor health services and so on. This prevailed after the resettlement also as most of the infrastructure had been damaged. So these people had more options in the informal sector than in the formal sector to make a living. So they made their living surrounding the informal sector. This is supported by government/ non-government officials as

"The money pumped in to the development of the livelihood is not given the expected outcomes" stated in sectorial meetings.

"If the funds pumped in to the districts were saved some districts could have been developed in a whole that there would have been no needs in the future"

"So much help have been done for the people in need so why the poverty is still at the same rate at the rural community"

Beneficiaries quote "many banks come and go explaining that they have great loan systems but we are unable to get them to develop our business"

"Loan systems are only for the people who have collaterals" "We need proper infrastructure and distribution channels to market our products" "we don't know how to take forward our business venture in a proper manner" "how to increase the quality of product to compete with other products"

The Banks quote "we are ready to give a way loans but the beneficiaries should provide a proper business plan which is feasible" "there are wonderful schemes but people tend to take loans from unauthorized systems or from finance institutes at a high rate of interest"

Government officials "There are many officers at the department to guide the business people to sustain their interventions" "Poverty level is still prevailing at the rural community", "There are many resources provided by the government to develop the rural economy"

By hearing so many quotes the researchers had so many questions in the mind to know really what is the reason holding back the communities in improving their livelihood and as the rural community is mostly depended on the informal sector for a living the researchers was inspired to conduct a research on the informal sector and the reasons contributing to the performance of the informal sector. When considering the sample population in the rural community the most vulnerable group of the rural poor are the women headed households where they don't get support from their husbands and struggle to make their family survive by only their earnings.

Often the poorest of the poor don't get the 
opportunity to enter in to the formal sector due to many reasons so they have no options that they have to choose the only option the informal sector. When considering poverty in the world of the millions of people living in poverty, women and children are the most detrimentally affected and it is believed that $60-70 \%$ of the world's poor are female and that the trend towards greater poverty among women is intensifying (Chant, 2007). So if long time sustainability and poverty reduction is to be done and decent wok agenda is to be taken forward the informal sector should be strengthen by reducing the factors hindering the informal sector the living standard of the poor could be increased and gradually the poverty could be reduced and through this the informal sector could be transformed in to the formal sector.

So through this study this study is trying to identify the factors influencing/hindering the performance of the informal sector where women headed households are participating and to find out ways in eliminating them and enhance their performance to the local economic development of Vavuniya District. When considering the Sri Lankan employment sectors it is evident that mostly the working population is depending on the informal sector in supporting the researcher's statement the Sri Lankan Government has stated this through the national human resources and employment policy for Sri Lanka.

"Subject to definitional and measurement, it is estimated that around two thirds of all working Sri Lankans are informally employed. Many of them earn low wages and are without social protection. Own account workers (around 32 percent of total employment) make up the bulk of those in informal employment. Many of these persons take up own account work because they lack either the skills, or advantages of location and social networks, to access wage employment"(The National Human Resources and Employment Policy for Sri Lanka, 2016, p.27).

Private formal employment only accounts for a fifth of the employed workforce. Males are more likely to be informally employed than females however when it comes to vulnerable women headed households in the war affected regions it's more likely these women make a living for these families depending in the informal sector. As these women are semi-skilled, less educated, due to social issues with economic factors hindering them they feel informal employment is the only way for survival. However though it plays an important role in an economy despite its importance, past statistics indicate that three out of five businesses fail within the first few months of operation (Kenya National Bureau of Statistics, 2007).

As one of the researcher is employed in a humanitarian organization, personal experience and observation realized this as a major issue when considering economic development through developing the informal sector. (District / divisional coordination meetings)

"Informal sector employment is scattered in allsectors of theeconomy-agricultural, industrial and services - but the relevant national data base is not adequate to 
judge the extent to which different sectors and sub-sectors absorb these workers Micro-enterprises - another category subject to definitional and measurement issues - are estimated to account for half of all informal employees" (The National Human Resources and Employment Policy for Sri Lanka, 2014, p.27)

Constraints on the growth of firms by size impede the rate at which firms grow into formal sector entities. Informal work generates relatively poor returns for most people engaged in it, and fails to reward skills at levels comparable with those in formal employment.

The majority of informal workers have lower general educational qualifications than formal workers (The National Human Resources and Employment Policy for Sri Lanka, 2014). They have dropped out of school system because of different reasons they are: family poverty which prevented completion of school careers, poor quality of teaching or poor facilities in schools, involuntary dropping out as only those with the necessary scholastic aptitude could make it to higher education and better paying jobs, Early marriage and the 30 years internal conflict.

People who didn't get the opportunity to attend school or those with technical abilities than academic abilities drop out of the school system and they cannot avail themselves of opportunities to enhance their skills and employability thereafter. When considering their health conditions, many workers are currently engaged in activities that are hazardous and harmful to their long-term health and well-being, and which will shorten their productive working life and harm not only them but the people depending on them. So it is clear the countries development is depending at a certain percentage on the informal sector employment and increasing the performance of the sector is very important for sustainable development. In support of this Schumpeter (2005) had stated, "Countries want to understand the determinants of and obstacles to entrepreneurship, and they need to analyse the effectiveness of different policy approaches" (p.13). Ultimately, policy makers must be guided, as far as possible, by evidence and facts. Understanding of the informal sector in Sri Lankan context is confused due to the lack of comparable empirical evidence and many questions remain unanswered. Based on these stated problem, this study has following objectives, (a) to identify the determinants of performance of informal sector and (b) to analyse the factor structure of the determinants of performance of informal sector.

\section{Review of Literature}

Theo et al. (2007) examined individual characteristics, parental influence, business motivation and goals, business strategies, goals and motives, networking and entrepreneurial orientation as influencing factors of performance. Enock (2010) found that access to finance and availability of management experience are the key socio-economic factors affecting the performance of businesses in Limuru Town Market. The other key factors that were found to affect businesses in Limuru Town Market positively are: access to business information, access to infrastructure and government policy and regulations (Enock, 2010). Cooper et al (1994) examined various factors which influence business performance 
such as: as experience, education, occupation of parents, gender, race, age, and entrepreneurial goals. Some other studies found training, economic, social and education are important factors in influencing the performance of informal sector (Fridah, 2012; Mahbub, 2000).

Similarly Samiti (2006) and Tan (2000) found three factors that are training, economic and social. However, Walelign and Wondimu (2002) found economic, education and training are influencing factors. A very similar study also found economic, education and training as important factors (Eshetu \& Zeleke, 2008). A different study by Karimi (2005) found two actors that are social and economic. Thibault et al. (2002) suggest that factors influencing business performance could be attributed to personal factors such as demographic variable and business factors such as amount of financing, use of technology, age of business, operating location, business structure and number of full-time employees as important factors in examining the performance as small scale business operators. However, Mirghafoori et al (2007) identified six categories of barriers affecting women entrepreneurs in Yazd province (Iran). Learner and Hisrich (1997) conducted a study on Israeli women entrepreneurs and categorized the factors that affect their performance into five perspectives, that is, motivations and goals, social learning theory (entrepreneurial socialization), network affiliation (contacts and membership in organizations); human capital (level of education, skills) and environmental influences (location, sectorial participation, and socio political variables).

\section{Exploratory Study}

As the objective of the study is to identify the factors that motivate / hinder the performance of the informal sector and to confirm the relationship between the factors and performance, initially this study review the literature to identify any factors which have been identified as motivators/hindrance for performance of informal sector by previous research. Then, this study employs exploratory study to explore the situation by generating information from relevant respondent group and do content analysis for finding factors which influence the performance of the sector.

Exploratory study, gathering descriptions from respondents and then classifying them into a number of categories by content analysis was employed. Participants were then asked to provide factors they experience as contributing factor for the performance of informal sector. This type of study fit the needs of the researcher to explore for information related to experience of informal sector performance, and permitted the participants to tell their stories and allowed the participants to provide a fresh comments about the factors. One hundred women headed households from the Vengalachddikulam Ds division form the Vavuniya District participated in this study.

In this study 96 women and 4 men participated, the 4 men were officers from the divisional secretariat as they were working with the creation of employments in the rural communities so their information was very valuable. There was a mix of aged group but $66 \%$ of them have education level equal or less than primary level education which makes 
Table 1: Characteristics of Respondents $(\mathrm{N}=100)$

\begin{tabular}{|c|c|c|c|}
\hline & & Frequency & Percentage \\
\hline \multirow[t]{2}{*}{ Gender } & Male & 4 & $4 \%$ \\
\hline & Female & 96 & $96 \%$ \\
\hline \multirow[t]{5}{*}{ Age groups } & Below 30 years & 17 & $17 \%$ \\
\hline & $31-40$ years & 32 & $32 \%$ \\
\hline & $41-50$ years & 35 & $35 \%$ \\
\hline & $51-60$ years & 11 & $11 \%$ \\
\hline & Above 61 & 5 & $5 \%$ \\
\hline \multirow[t]{7}{*}{ Education Level } & No attended school & 4 & $4 \%$ \\
\hline & Primary Education & 62 & $62 \%$ \\
\hline & $\mathrm{O} / \mathrm{L}$ & 14 & $14 \%$ \\
\hline & $\mathrm{A} / \mathrm{L}$ & 9 & $9 \%$ \\
\hline & Degree & 7 & $7 \%$ \\
\hline & Masters & 2 & $2 \%$ \\
\hline & Diploma & 2 & $2 \%$ \\
\hline \multirow[t]{6}{*}{ Position } & Not Married & 5 & $5 \%$ \\
\hline & Married & 29 & $29 \%$ \\
\hline & Separated from Husband & 32 & $32 \%$ \\
\hline & Divorced & 2 & $2 \%$ \\
\hline & Widow & 30 & $30 \%$ \\
\hline & Husband gone missing & 2 & $2 \%$ \\
\hline \multirow[t]{9}{*}{ Year of Experience } & Less than 02 years & 21 & $21 \%$ \\
\hline & $02-05$ years & 40 & $40 \%$ \\
\hline & $06-10$ years & 11 & $11 \%$ \\
\hline & $11-15$ years & 4 & $4 \%$ \\
\hline & $16-25$ years & 1 & $1 \%$ \\
\hline & More than 25 years & 1 & $1 \%$ \\
\hline & Not directly involved & 11 & $11 \%$ \\
\hline & Stopped the intervention & 2 & $2 \%$ \\
\hline & Not started yet but willing to start & 9 & $9 \%$ \\
\hline Total & & & 100 \\
\hline
\end{tabular}

Source: Survey Data

it hard for them to do business at an effective manner.

A questionnaire was developed to gather information which has two section which section one gather the demographic information of the respondents where in the second section the following questions were asked from the beneficiaries, "In your experience what are the success factors contributing to the betterment of the Informal sector Employment"; "In your experience what are the factors hindering the 
Table 2: Success factors contributing to the betterment of the Informal sector Employment

\begin{tabular}{|c|c|c|c|}
\hline Response & Frequency & $\%$ & Emerging Success Factors \\
\hline Training helped me to enhance my skills & 25 & \multirow{4}{*}{78} & \multirow{4}{*}{$\begin{array}{l}\text { Training and Skills support } \\
\text { factors }\end{array}$} \\
\hline Training helped me to do business properly & 18 & & \\
\hline Training helped me to use new technologies & 8 & & \\
\hline Training helped me to recognize customers & 9 & & \\
\hline Good market opportunities & 34 & \multirow{3}{*}{55} & \multirow{3}{*}{ Economic factors } \\
\hline Raw materials available & 14 & & \\
\hline Finance opportunities & 07 & & \\
\hline Assistance received by children & 16 & \multirow{5}{*}{41} & \multirow{5}{*}{ Social support factors } \\
\hline Assistance received by parents & 11 & & \\
\hline Assistance received by in laws & 04 & & \\
\hline Encouragement by society & 04 & & \\
\hline Support received from Government & 06 & & \\
\hline Effort put in by individual & 5 & 0.05 & \\
\hline Word of mouth Advertisement & 4 & 0.04 & \\
\hline Positive Environment changes & 4 & 0.04 & \\
\hline Awareness Tours and programmes & 3 & 0.03 & \\
\hline Knowledgeable staff at government offices & 2 & 0.02 & \\
\hline
\end{tabular}

Source: First study

betterment of the Informal sector Employment"; "As a person involved in the Informal sector Employment what would do you recommend to improve the Informal sector Employment". Items generated as the responses to these three questions were triangulated to find common features of factors which motivating (success factors) / hindering factors.
Depending form the first stage findings training and skills and education were selected as internal factors while economic and social were selected as external factors for the second stage of the study. The sample of hundred generated 192 items for question number one, 279 items for question number two and 187 items for question number three. The exploratory study employ convenient sampling, thereby subjects 
Table 3: The factors hindering the betterment of the Informal sector Employment.

\begin{tabular}{|c|c|c|c|}
\hline Response & Frequency & $\%$ & Emerging Success Factors \\
\hline Access to working capital & 16 & \multirow{7}{*}{88} & \multirow{7}{*}{ Economic factors } \\
\hline Insufficient working capital & 14 & & \\
\hline Unable to obtain loans from banks & 11 & & \\
\hline Transport & 23 & & \\
\hline Competition Market & 14 & & \\
\hline Problem in getting the needed raw materials & 6 & & \\
\hline Capital and input price increase & 4 & & \\
\hline Issues created by societies & 26 & \multirow{3}{*}{61} & \multirow{3}{*}{ Social support factors } \\
\hline Gender base violence in family & 21 & & \\
\hline Being without husband difficult to protect & 14 & & \\
\hline Being not educated running business ineffective & 25 & \multirow{6}{*}{60} & \multirow{6}{*}{ Education factors } \\
\hline less education unable to register the business & 13 & & \\
\hline Unable to meet the legal requirements & 05 & & \\
\hline Not knowing to calculate income / profit & 10 & & \\
\hline Unable to keep accounts as not educated & 05 & & \\
\hline Played out by business people as not educated & 02 & & \\
\hline Unable to carry out my business as not trained & 26 & \multirow{2}{*}{31} & \multirow{2}{*}{$\begin{array}{l}\text { Training and Skills support } \\
\text { factors }\end{array}$} \\
\hline Unable to improve the business as no technology & 05 & & \\
\hline Diseases & 9 & 0.09 & \\
\hline Sickness & 9 & 0.09 & \\
\hline Attitude problems & 7 & 0.07 & \\
\hline Labour problems & 4 & 0.04 & \\
\hline Less unity among group business & 3 & 0.03 & \\
\hline Debt burden & 3 & 0.03 & \\
\hline Less spacing facilities at home for business & 2 & 0.02 & \\
\hline Less risk taking ability & 2 & 0.02 & \\
\hline
\end{tabular}

Source: First study

are selected on an ad hoc basis. Next, the author classified the items into (n) categories based on the similarity of item content. Author categorized all the items into a small number of mutually exclusive categories.

Table 2, 3 and 4 present a description of the categories and the frequency of distribution of the generated items. To reduce the number of categories to a more manageable number, conceptually similar categories were grouped into broader, more abstract factors, then categories were combined into broader, conceptually meaningful factors. Training 
Journal of Management - Vol. 12 No.1 April 2015

Table 4: Rrecommendations to improve the Informal sector Employment:

\begin{tabular}{|c|c|c|c|}
\hline Response & Frequency & $\%$ & Emerging Success Factors \\
\hline Easy loan systems fits to poor enterprises & 40 & \multirow{3}{*}{$84 \%$} & \multirow{3}{*}{ Economic factors } \\
\hline Solutions to overcome capital requirements & 22 & & \\
\hline Create marketing opportunities & 22 & & \\
\hline Improve production quality by proper trainings & 52 & \multirow{2}{*}{$57 \%$} & \multirow{2}{*}{$\begin{array}{l}\text { Training and Skills support } \\
\text { factors }\end{array}$} \\
\hline New technology improvements and training & 05 & & \\
\hline Government assistance for tools and equipment & 18 & \multirow{2}{*}{$25 \%$} & \multirow{2}{*}{ Social support factors } \\
\hline Legal help & 7 & & \\
\hline Increase the number of production & 5 & 0.05 & \\
\hline Advertisement improvement & 5 & 0.05 & \\
\hline Education & 4 & 0.04 & \\
\hline Environment for women to work from home & 3 & 0.03 & \\
\hline Women rights awareness at village levels & 2 & 0.02 & \\
\hline Business awareness ideas at school level & 2 & 0.02 & \\
\hline
\end{tabular}

Source: first study

and skills, economy, social and education as major factors were identified from the original items generated by the respondents. In order to ensure internal validity, these four factors are compared with the factors found from the literature to refine to ensure the match between factors found from the literature and participant reality. Based on this, the researcher extrapolated the factors which influence the performance of the informal sector.

When considering the findings $78 \%$ of the respondents have responded that they feel the success factor is training and skills factors influence for the success of their business while $52 \%$ by the Economic factors and $41 \%$ by the social factors (See Table 2) Table 3 presents a description of the categories and the frequency of distribution of the 192 items. Similarly, under the hindering factors $88 \%$ of the respondents have responded that economic factors like access to finance, marketing, transport, raw material problems as the major issue to carry forward their business. While $61 \%$ of the respondents mentioned that social factors and $60 \%$ mentioned that education factors are hindering their business. As recommended by the respondents $84 \%$ have mentioned that the Economic factors should be improved to enhance the performance of the informal sector. While $57 \%$ of them have recommended to improve the training and skills part while $25 \%$ of them have mentioned that the social part should be improved to enhance the informal sector (See Table 4).

When the triangulation is carried out comparing all three tables based on the percentage of frequencies Economic factors has been identified as the first factor, $88 \%$ from table two 
and $84 \%$ from table three offering this response makes the first factor. The $78 \%$ of frequencies from table one $57 \%$ from table three are found to be as training and skills making this as the second commonly cited factor. $61 \%$ from table two and $41 \%$ from table one implies this factor can be considered as the third important factors. Only $60 \%$ of the respondents identified education factor and making this factor as important. The important factor and making these factors next important factor respectively. Item group with less frequencies were eliminated with an assumption, those are insignificance. As a results, the rest of the items were eliminated from further study.

Examples of items that suggested that 'Training and skills' was a factor that motivate/impeded performance: "As I received proper training it helped me to carry out my business properly". Examples of item made by the respondents that suggested that 'Economic' as a factor motivated/impeded performance." "Unable to obtain loans from banks". Examples of items that suggested that 'Social' was a factor that motivate/impeded performance: "Gender base violence in family". Examples of comments made by respondents that suggested 'Education' had an effect on performance: "By less education level unable to run the business properly". The results of the study at stage 1 ended up with four important factors of training and skills, economic, social and education

\section{Development of the Questionnaire and Primary Analysis}

To measure each of the four factors found in the exploratory study, five to six items were developed from the original items generated by the respondents. These items were developed in such a way as to represent all other items based on the frequencies of initial categories for incidents, which resulted in 20 items. The questionnaire comprised of two sections: Section A comprised the demographic characteristics of the participants; Section B consists of five sub-sections which measure: training and skills, economic, social, education and performance. The items in section B were scored based on five-point rating scale ranging from $\mathrm{N}=$ Never to $\mathrm{A}=$ Always All items were originally developed in English and translated into Sinhala and Tamil via a double blind back-translation technique (Brislin, 1980). First the new scale was administered to thirty participants who are in the same characteristics of the population. Minor modifications were made in the scale after the initial administration of the test. For making the meaning of words and items more clear five items were reworded. Editing was done on the items to prevent double-barrelled questions, and to avoid vague questions or phrases. And due to hesitation of the some of the respondents to mention certain issues, that information was removed from the final version of the questionnaire. The scale was checked to confirm normal distribution. Reliability Cronbach alpha coefficients was 0.76 for section one, 0.84 for sub-section two, 0.83 for sub-section three, 0.79 for subsection four, and 0.84 for sub-section five and 0.79 .

\section{Factor Analysis}

As part of the analysis, in order to verify the construct validity, a factor analysis, a data reduction method, was conducted utilizing Principal Component Analysis (PCA) with the Varimax rotation method. Factor analysis was 
done for the items generated by the Study 1 .

In order to ensure that the questions asked relate to the construct that intended to measure factor analysis is used to develop questionnaire. Generated question based on the initial study with the elements in the target population and came up with 20 possible questions to include. Each question was a statement followed by a five-point Likert scale ranging from "never" through "always". To breakdown all of these questions into specific forms of factors, with a sample size of 300 . Correlation coefficient fluctuate from sample to sample, much more so in small samples than in large. Therefore, the reliability of factor analysis is also dependent on sample size. Field (2005) reviews many suggestions about the sample size necessary for factor analysis and concludes that it depends on many things. In general over 300 cases is probably adequate but communalities after extraction should probably be above 0.5 (Field, 2005). Before running the factor analysis, data were screened by checking for normality, linearity, and multicollinearity. The scales used for were self-reported. Therefore, it is possible to have influence of common method bias on the results of these findings. The correlation matrix of the variables was investigated and no multicolliearity was detected. Other than this, the examination of the correlation matrix showed no multicollinearity because of the absence of bivariate correlations above .90 (Tabachnick \& Fidell, 2007).

KMO and Bartlett's test of sphericity produces the Kaiser-Mayer-Olkin measure of sampling adequacy and Bartlett's test (Field, 2005). The value of KMO should be greater than 0.5 if the sample is adequate. The KMO statistic varies between 0 and 1 . For these data the value is 0.67 which fall into the range of being good. Therefore, it is possible to say that factor analysis is appropriate for these data and this value of KMO means the research has good number of samples.

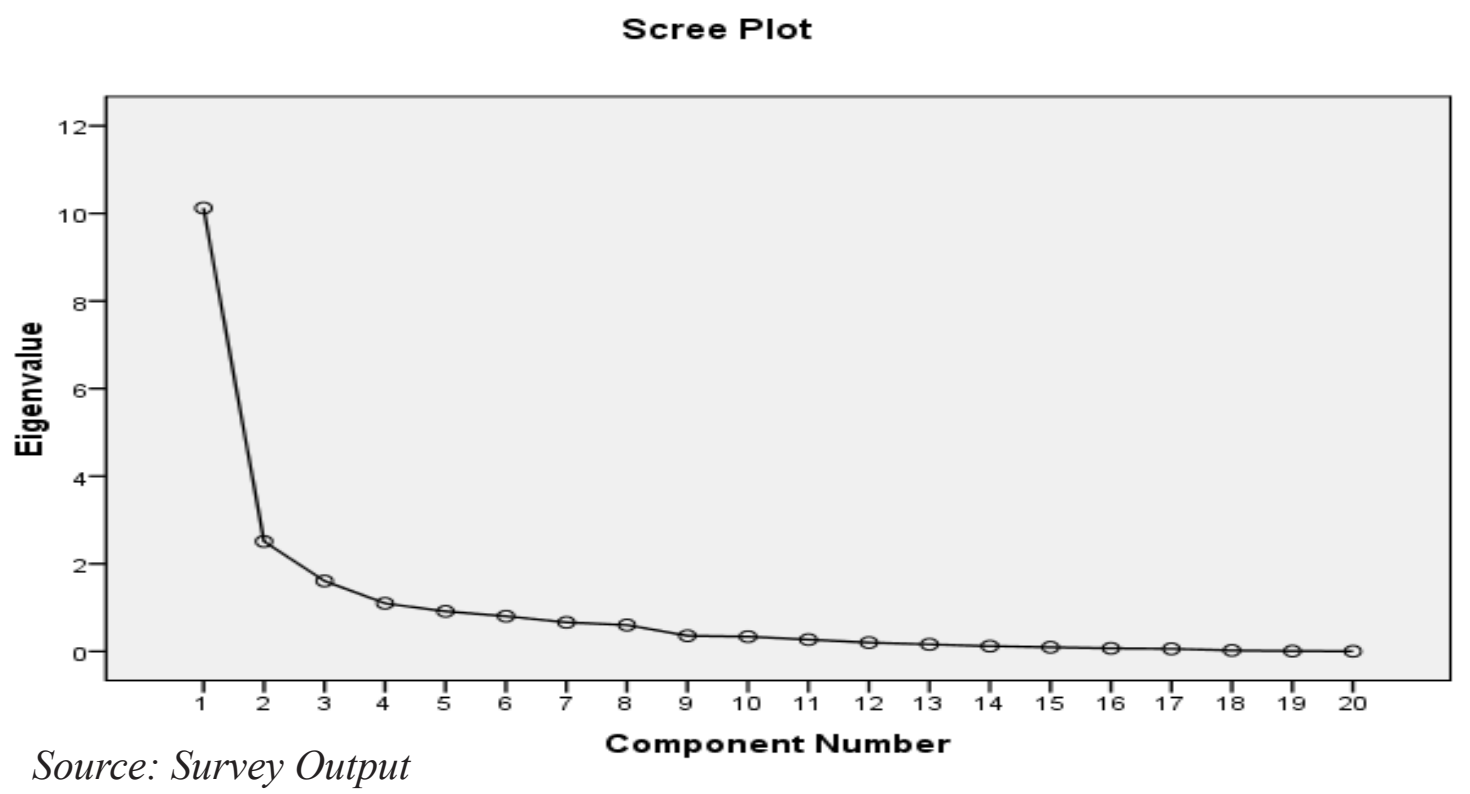

Figure 1: Eigen Value and Scree Plot 
Further, Bartlett's test is highly significant $(\mathrm{p}<0.001)$, and therefore factor analysis is appropriate. Since the items have communalities greater than 0.5 , these items contribute to the construct significantly. Factor analysis generates four rotated component for the variable which has higher Eigenvalue (more than 1). This is shown in the following Scree Plot.

The scree plot is shown above with a point of inflexion on the curve. This curve begins to tail off after four factors. Therefore, it is possible to justify retaining four factors.

Factor Analysis was conducted, which resulted in a four factor solution that accounted for $76 \%$ of the variance. The SPSS output

Table 5: Results of the Factor Analysis

Total Variance Explained

\begin{tabular}{|c|c|c|c|c|c|c|c|c|c|}
\hline \multirow{2}{*}{ Component } & \multicolumn{3}{|c|}{ Initial Eigenvalues } & \multicolumn{3}{|c|}{ Extraction Sums of Squared Loadings } & \multicolumn{3}{|c|}{ Rotation Sums of Squared Loadings } \\
\hline & Total & $\%$ of Variance & Cumulative $\%$ & Total & $\%$ of Variance & Cumulative $\%$ & Total & $\%$ of Variance & Cumulative $\%$ \\
\hline 1 & 10.123 & 50.613 & 50.613 & 10.123 & 50.613 & 50.613 & 7.129 & 35.647 & 35.647 \\
\hline 2 & 2.510 & 12.548 & 63.162 & 2.510 & 12.548 & 63.162 & 3.152 & 15.758 & 51.405 \\
\hline 3 & 1.607 & 8.035 & 71.197 & 1.607 & 8.035 & 71.197 & 2.653 & 13.267 & 64.672 \\
\hline 4 & 1.096 & 5.482 & 76.680 & 1.096 & 5.482 & 76.680 & 2.401 & 12.007 & 76.680 \\
\hline 5 & .913 & 4.564 & 81.243 & & & & & & \\
\hline 6 & .803 & 4.013 & 85.256 & & & & & & \\
\hline 7 & .661 & 3.305 & 88.562 & & & & & & \\
\hline 8 & .600 & 3.002 & 91.564 & & & & & & \\
\hline 9 & .356 & 1.781 & 93.345 & & & & & & \\
\hline 10 & .336 & 1.680 & 95.025 & & & & & & \\
\hline 11 & .268 & 1.338 & 96.363 & & & & & & \\
\hline 12 & .200 & 1.000 & 97.363 & & & & & & \\
\hline 13 & .159 & .794 & 98.157 & & & & & & \\
\hline 14 & .120 & .598 & 98.756 & & & & & & \\
\hline 15 & .094 & .468 & 99.224 & & & & & & \\
\hline 16 & .069 & .345 & 99.568 & & & & & & \\
\hline 17 & .057 & .286 & 99.855 & & & & & & \\
\hline 18 & .022 & .112 & 99.966 & & & & & & \\
\hline 19 & .006 & .029 & 99.995 & & & & & & \\
\hline 20 & .001 & .005 & 100.000 & & & & & & \\
\hline
\end{tabular}

Source: SPSS output lists the eigenvalues associated with each factor. The eigenvalues associated with each factor represent the variance explained by that particular linear component and SPSS also displays the eigenvalue in terms of the percentage of variance explained; as such factor 1 explains $50.613 \%$ of total variance. It is clear that the first few factors explain relatively large amounts of variance (especially factor 1) whereas subsequent factors explain only small amounts of variance. SPSS then extracts all factors with eigenvalues greater than 1, which leaves with four factors (factor 2 with $12.548 \%$, factor 3 with $8.035 \%$, factor 4 with $5.482 \%$ ).

The questions that load highly on factor 1 seem to all relate to training and skills. Therefore factor 1 is labeled as training and skills. The 
questions that load highly on factor 2 all seem to relate to different aspects of education; therefore, this factor labelled as education factor. The questions that load highly on factor 3 all seem to relate to social; therefore, third factor is labelled as social factors. Finally, the questions that load highly on factor 4 all contain some component of economic related; therefore, this factor is labelled as economic factor. This analysis reveal that the initial questionnaire, in reality, is composed of four sub scales: training and skills, economic, social and education.

To conclude, the present study supports a four factor model of determinants of performance of informal sector in Sri Lanka. These factors are consistent with the literature and the results of the exploratory study. The results also indicate that factors identified in exploratory study fall

Table 6: Results of Factor Analysis (Rotated Component Matrix)

\begin{tabular}{|c|c|c|c|c|}
\hline \multirow{2}{*}{ Items } & \multicolumn{4}{|c|}{ Component } \\
\hline & 1 & 2 & 3 & 4 \\
\hline I have got entrepreneurship training from registered government / private institutes & .868 & & & \\
\hline I have got marketing training from registered government/ private institutes & .875 & & & \\
\hline $\begin{array}{l}\text { I have got planning and financial reporting training from registered government } \\
\text { private institutes }\end{array}$ & .897 & & & \\
\hline I have got customer relations training from registered government/ private institutes & .877 & & & \\
\hline I have got technical skill training from registered Vocational training institute & .883 & & & \\
\hline $\begin{array}{l}\text { I am satisfied with the financial access given by micro finances and other lending } \\
\text { institutions }\end{array}$ & & .452 & & \\
\hline I can borrow money even without titled assets as a collateral & & .752 & & \\
\hline I have access to market for my products & & .797 & & \\
\hline Adequate infrastructure facilities are available & & .567 & & \\
\hline I have access to necessary inputs (raw materials) & & .809 & & \\
\hline The societies attitude towards my products/services is positive & & & .679 & \\
\hline Without the help of my husband I am not unsecured and able to carry out my business & & & .712 & \\
\hline I am not affected by gender inequalities and supported by the society & & & .639 & \\
\hline I never encounter harassments by my family members during my business process & & & .802 & \\
\hline I never encounter harassments by the society during my business process & & & .841 & \\
\hline I have an access to information to exploit business opportunities & & & & .464 \\
\hline I have financial knowledge to carry forward the business & & & & .654 \\
\hline My education level is a success factor in carrying out my business & & & & .521 \\
\hline My education level helped me to register my business & & & & .763 \\
\hline $\begin{array}{l}\text { I have enough knowledge to solve the needed legislation requirements of the } \\
\text { Government regarding my business }\end{array}$ & & & & .553 \\
\hline
\end{tabular}

\section{Source: SPSS output}


neatly into the theoretically consistent factors found in the literature.

Table 1 lists the 20 items, their loadings, and the theoretical factor category that each item was initially intended to measure. Items loading greater than .40 were classified as representing a particular factor. As a result, all 20 items loaded in to four factors (see Table 5). The resulting model supported the substantive categories of factors consistent to the factors originally identified in the exploratory study. The reliability values of each factors shows all the factors are reliable.

\section{Implications of the Study}

This study will benefit in three ways namely practical, theoretically and nationally. When considering the practical part it will provide evidence on understanding the real factors influencing the informal sector in Vavuniya district which will help the individuals to understand the possibilities in how they could improve their enterprise.

On the other the findings of this study will make a fresh contribution to the empirical evidence for researchers where it will be used for future researchers and for understanding the informal sector in Sri Lanka specially the Vavuniya district context.

Finally it will assist the policy makers, donors and the stakeholders to take policy level decisions on improving the informal sector in Sri Lanka. The findings of this study will give necessary information to the policy makers to create new policies to help the informal sector development, District Secretariat to guide their human resource namely Human Resource Development Officers, Skills Development
Officers, Women Development Officers and Samurdhi Officers to focus on informal sector development and enhance this sector to increase the local economic development and for donor agencies to plan and develop new project activities as well to evaluate their past projects in this sector its performance and success level of their project. In addition, this will help to increase the living standards of the informal sector beneficiaries.

\section{References}

Brislin, R.W. (1980). Translation and Content Analysis of Oral and Written Material. In: H.C. Triandis \& J.W. Berry (eds.), Handbook of Cross-Cultural Psychology, 2, 389-444. Boston: Allyn \& Bacon.

Chant, S. (2007). Poverty begins at home? Questioning some (mis) conceptions about Children, poverty and privation in femaleheaded households, London school of economics

Cooper, Arnold C., F. Javier Gimeno Gascon, \& Carolyn Y. Woo (1994). Initial human and financial capital as predictors of new venture performances. Journal of Business Venturing, 9, 371-395.

Enock, N. (2010). What are the factors limiting the success and/or growth of small businesses in Tanzania: An empirical study on small business growth. (Master's thesis, University of Arcada). Arcada, Tanzania.

Eshetu, B., \& Zeleke, W. (2008).Women entrepreneurship in micro, small and medium enterprises: The case of Ethiopia. Journal of international women'sstudies. 10(2), 3-5. 
Field, A. (2005), Discovering Statistics Using SPSS, 2nd ed, SAGE, London.

Fridah, M. M. (2012). The Challenges Facing Small-Scale Women Entrepreneurs: A Case of Kenya. International Journal of Business Administration, 3(2), 23-45.

Karimi, Z. (2005). The role of government support in expanding entrepreneurship among women: Case Study: women's cooperatives in Mazandaran province, the first conference women entrepreneurs and the challenges facing it, Association of Women Entrepreneurs' manager.

Learner, M., Brush, C., \& Hisrich, R. (1997). Israel Women Entrepreneur: An Examination of factors affecting Performance. Journal of Business, 122129.

Mahbub, U. H. (2000). Human Development Centre, Human Development in South Asia: The Gender Question (Oxford University Press): Karachi.

Mbugua, S. K., Agnes, N. O., \& Ibrahim, T. (2014). Factors Affecting the Performance of Small and Micro Enterprises in Limuru Town Market of Kiambu County, Kenya. International Journal of Scientific and Research Publications, 4 (12), 34-48.

Mirghafoori, S. H., Sayadi Toranloo, H., \& Fahimi Hanzaei, S. (2007). Identifying and ranking barriers affecting entrepreneurial activity of women using techniques mcdm: Women Entrepreneurs in Yazd province, Journal of Women's Studies, 1(2), 33-61.
Samiti, V. (2006). A research study on Entrepreneurial Challenges for SC Persons in India. New Delhi: Planning Commission Government of India Yojana Bhawan.

Schumpeter, Joseph, A. (2005). Development, Journal of Economic Literature, 43, 108120.

Tan, J., \& Young, E. (2000). Entrepreneurial Infrastructure in Singapore: Developing a Model and Mapping Participation, Journal of Entrepreneurship. 9(1), 230-245.

Tabachnick, B. G., \& Fidell, L. S. (2007). Using multivariate statistics (5th ed.).Boston, MA: Allyn \& Bacon.

Theo, W. M., \& Chong, S. (2007). Theorizing a framework of Factors Influencing performance of Women Entrepreneurs in Malaysia. Journal of Asia Entrepreneurship and Sustainability, 3(2), 1-17.

Thibault, M., Wilcock, A., \& Kanetkar, V. (2002). An exploratory study of factors influencing sales performance of small and medium -sized enterprises .Proceedings of the Administrative Sciences association of Canada. Winnipeg, Manitoba.

The National Human Resources and Employment Policy for Sri Lanka. Retrieved on 01-2-2016 from http://www. nhrep.gov.lk/images/pdf/nhrep_final.pdf

Resource profile \& statistical of Vavuniya district (2015). District planning secretariat district secretariat Vavuniya

Sri Lanka Labour Force Survey Annual Report (2014), Sri Lanka.

Kenya National Bureau of Statistics (2007), Kenya. 